\title{
Proturječnosti stambenih politika u razvijenim državama EU-a
}

\author{
Josip Pandžićc \\ Pravni fakultet Sveučilišta u Zagrebu, Studijski centar socijalnog rada, \\ Hrvatska \\ e-mail:jpandzic@pravo.hr
}

\begin{abstract}
SAŽETAK Razvoj stanovanja pokazao se kroz pola stoljeća komparativnih istraživanja ambivalentnim i empirijski teško mjerljivim predmetom istraživanja. S vremenom su istraživački napori urodili konstrukcijom tročlane podjele na jukstapozicijsku, konvergencijsku i divergencijsku paradigmu. Divergencijska paradigma, u koju se ubrajaju različite „teorije srednjeg dometa“, trenutno je najrazvijenija u komparativnim stambenim studijama te će biti korištena pri preliminarnom opisu razlika i sličnosti razvijenih država članica EU-a u pogledu stanovanja. Unatoč marginaliziranom istraživačkom statusu konvergencijske stambene paradigme, cilj je ovog rada njezina revitalizacija u stambenim studijama kroz komparativnu analizu proturječnosti konvergencijskih trendova liberalizacije i europeizacije stambenih politika koji se izravno ili neizravno odnose na stambene promjene u razvijenim državama članicama EU-a. Proturječnosti konvergencijskih trendova stambenih politika zasebno su problematizirane na primjeru globalne financijske krize 2008. godine i posljedične krize u EU-u te njihovog utjecaja na stanovanje.
\end{abstract}

Ključne riječi: stanovanje, razvoj, divergencija, konvergencija, proturječnost, liberalizacija, europeizacija, kriza.

1 Mag. soc., doktorand poslijediplomskog doktorskog studija socijalne politike, zaposlen na Katedri za socijalnu politiku Studijskog centra socijalnog rada pri Pravnom fakultetu Sveučilišta u Zagrebu. 


\section{Uvod}

Gotovo notorna kompleksnost stanovanja kao predmeta istraživanja dugo je vremena odvraćala istraživače od sustavnog proučavanja stambenih procesa i problema. ${ }^{2}$ Stan je podjednako sredstvo za podmirivanje stambenih potreba (sklonište), bogatstvo koje se može konzumirati, prodavati, nasljeđivati i iznajmljivati (kapital) te mjesto odvijanja emocionalnog života ukućana (dom). Stambeno je zbrinjavanje „klimavi stup socijalne države” (Torgersen, 1987.) jer je u većoj mjeri komodificirano $^{3}$ od drugih vrsta socijalnih transfera (socijalna sigurnost - mirovine, naknade za nezaposlenost, bolest i invaliditet, socijalna pomoć) i usluga (zdravstvena skrb, obrazovanje) države, pa se dominantno osigurava na (stambenom) tržištu kupnjom objekta ili najmom. Stanovanje je stoga od velikog broja istraživača socijalne politike unaprijed isključeno iz skupa područja u nadležnosti socijalne države jer se uvriježilo mišljenje da, unatoč potrebi minimalnog regulativnog tretmana usmjerenog stambenoj potrošnji, tržište uglavnom dobro funkcionira u slučaju stambene opskrbe (Barr, 2012.).

Komparativna istraživanja stanovanja ipak su u proteklih pola stoljeća uznapredovala od formulacija pojednostavljenih objašnjenja i neopreznih predviđanja budućih razvojnih trendova do interdisciplinarnog statusa utemeljenog na različitim teorijskim pristupima, sofisticiranim metodama analize i pouzdanim izvorima podataka. Najveći prijepori u stambenim studijama (engl. bousing studies) ${ }^{4}$ datiraju iz druge polovine 1980-ih i 1990-ih, a temelje se na opreci dvaju objašnjenja razvoja stanovanja: konvergencije i divergencije. Drugim riječima, istraživači stanovanja pokušavali su dokazati približavaju li se uspoređivani stambeni sustavi ${ }^{5}$ - uglavnom razvijenih ${ }^{6}$

2 Ovaj je rad nastao uz potporu međunarodnog projekta o stambenom razvoju OIKONET (www.oikonet.org).

3 Riječ je o marksističkom terminu koji označava „po-robljavanje“, odnosno pretvaranje dobara, usluga, radne snage i novca u razmjenjive proizvode (robu), dok je njegov antipod (dekomodifikaciju) u socijalnoj politici popularizirao Esping-Andersen (1990.:3) ustvrdivši kako „temeljni kriterij socijalnih prava treba biti stupanj u kojem ona omogućavaju pojedincima da ostvare svoje životne standarde nezavisno od čistih tržišnih sila“. Sukladno tome dekomodifikacija podrazumijeva ,isključivanje određenih roba i usluga ili rada iz tržišta i njihovo distribuiranje prema drugim (netržišnim ili manje tržišnim) kriterijima" (Bežovan i sur., 2005.:429).

4 Prema Kemenyu (1992.:8), stambene studije predstavljaju „proučavanje socijalnih, političkih, ekonomskih, kulturalnih i drugih institucija i odnosa koji konstituiraju opskrbu i iskorištavanje građevina".

5 U ovom se radu stambeni sustav shvaća kao „specifični aranžman i kompozicija stambenih statusa, stupanj univerzalnih transfera (porezni i sustav subvencija koji cilja na vlasnički, socijalno najamni i privatni najamni sektor), kao i specifični oblici stambene opskrbe (promocije i proizvodnje)" (Arbaci, 2007.: 410-413).

$\mathbf{6}$ Uzorak zemalja u nastavku određen je rezultatima komparativnih divergencijskih stambenih studija, pa su izostavljene postkomunističke zemlje, koje se ne mogu svrstati u koherentan klaster te ih se naziva tranzicijskima „prema početnim postavkama“ (engl. by default) (Stephens, Lux i Sunega, 2015.), a bit će predmet analize rada u pripremi (Pandžić, 2017.). 
- država jednom modelu zbog djelovanja istih strukturalnih uzročnika ili je, naprotiv, riječ o međusobnom udaljavanju stambenih sustava zbog prisutnosti različitih kulturnih, političkih, gospodarskih ili nekih drugih oblika institucionalnog naslijeđa.

U prvom dijelu rada pokazuju se prednosti divergencijske teorije u objašnjenju razvoja stanovanja naspram alternativnih teorija. Divergencijske teorije pokazale su se iznimno korisnima pri opisu trenutačne panorame stambenih sustava različitih država na temelju određenih indikatora i kao odlično heurističko sredstvo u istraživanju. Ipak, potrebno je revitalizirati konvergencijsko objašnjenje kao izvor spoznaje o stambenim promjenama jer je stanovanje divergencijski shvaćeno kao slabo promjenjivi (statični) čimbenik različitih društava pa se može pronaći i tvrdnja da sve „komparativne stambene studije objašnjavaju razlike, ali ostaju slijepe za zajedničke putanje“ (Aalbers, 2016.:5). Razvijene države članice EU-a koje čine uzorak u ovom radu odabrane su na temelju razlika utvrđenih dominantnim divergencijskim teorijama, čime je istodobno odano priznanje dosezima divergencijske analize te stvoren komparativni kontekst unutar kojega djeluju konvergentni trendovi stambenog razvoja. U drugom dijelu rada spomenuti konvergentni trendovi stambene politike nazivaju se „liberalizacija“ i „europeizacija“ te se pritom iznosi teza da je riječ o proturječnim trendovima, koji mogu prouzročiti ozbiljne negativne posljedice na stambeno zbrinjavanje i općenito razvoj u odabranim državama iz analize. To se dodatno potkrjepljuje relevantnim empirijskim longitudinalnim indikatorima. U posljednjem se, trećem dijelu na temelju teze o postojanju proturječnosti konvergencijskih stambenih trendova šire problematizira stanovanje u kontekstu razdoblja globalne financijske krize iz 2008. godine i posljedične krize u EU-u. U zaključnoj raspravi preispituje se trenutno stanje i predstavlja primjere stambenih sustava i država članica relativno otpornih na šokove i krize.

\section{Konvergencija i divergencija u stanovanju razvijenih europskih zemalja}

Porastom broja komparativnih studija stambenih sustava razvijenih zemalja tijekom 1980-ih i 1990-ih godina znanstveno su legitimirane interdisciplinarne stambene studije. Utjecajna sistematizacija područja komparativnih stambenih studija koju su izradili Kemeny i Lowe (1998.) razlikuje tri ideal-tipski koncipirane vrste „analiza“ (škole mišljenja, pristupa, paradigmi) prema korištenju različitih razina upotrijebljene generalizacije u objašnjenjima.

Najnižu razinu predstavljaju partikularističke „jukstapozicijske analize“, koje nisu teorijski utemeljene niti sadržavaju pokušaj generalizacije, već su uglavnom detaljni empirijski opisi stambenih sustava država koje se uspoređuju bez objašnjenja kriterija odabira i eksplanatornog okvira usporedbe (usp. Mullins i Maurie, 2006.).

Najvišu generalizacijsku razinu zauzimaju univerzalističke „konvergencijske analize“, u kojima se ističu sličnosti među stambenim sustavima zemalja. Te se „analize“ mogu nazvati i teleološkim te „unilinearnim“ jer pretpostavljaju napredak različitih društava prema istom razvojnom cilju (univerzalna socijalna država, neregulirano tržište i sl.). Razlike među zemljama zabilježene tijekom istraživanja često su u kon- 
vergencijskim analizama odbačene kao „devijacije“, „varijacije“ ili „iznimke koje potvrđuju pravilo“. Preteče tih analiza datiraju iz unazad pola stoljeća, čemu svjedoči Donnisonova (1967.) klasična stambena studija konvergencijske orijentacije, u kojoj se modernizacijskom tezom o postojanju „logike industrijalizma“ pokušava objasniti linearnu konvergencijsku putanju stambenih politika razvijenih zemalja kao posljedicu istovjetnosti procesa društvene promjene - gospodarskog razvoja i povoljnih demografskih kretanja - unatoč njihovim početnim institucionalnim razlikama. Prema takvoj „logici industrijalizma“, društveni će razvoj pratiti povećanje opsega djelovanja i organizacije stambene politike kroz kontinuum sukcesivnih oblika: slučajna $\rightarrow$ rezidualna $\rightarrow$ opsežna (stambena politika). Konvergencijska je analiza tijekom kasnih 1970-ih i 1980-ih godina postala svojstvena i neomarksističkim istraživačima urbanih i stambenih tema. Castellsovi (1977., 1980.) funkcionalistički radovi o „urbanom pitanju“ predstavljaju konvergencijsku analizu koja se sastoji od generalizacije na temelju jednog (francuskog) slučaja: neuspjeh tržišnog podmirivanja stambenih potreba i općeniti manjak profitabilnosti proizvodnje „kolektivnih dobara“ za kapitalističku klasu zahtijeva državni intervencionizam u gradovima, uz pomoć kojeg se nadalje reproducira radna snaga zbog njezine „strateške uloge“ u „procesu proizvodnje“. Slučajevi koji odstupaju od vizije budućnosti obilježene stambenom krizom i posljedičnim porastom državnog intervencionizma u proizvodnji urbanih sredstava „kolektivne potrošnje“ (infrastrukture) objašnjavaju se posljedično kao „iznimke“ ili se navodi postojeća tradicija snažnog intervencionizma uz naglašavanje „razvojnih specifičnosti“. Definitivni primjer neomarksističke, ali i konvergencijske analize uopće predstavlja Harloeov (1995.) rad o razvoju socijalnog stanovanja u 20. stoljeću na primjeru šest zemalja - Velike Britanije, (Zapadne) Njemačke, Francuske, Nizozemske, Danske i SAD-a. Masovna opskrba socijalnim stanovanjem, kao eklatantni primjer državnog intervencionizma u područje stanovanja, nije svojstvena razvijenim kapitalističkim zemljama, već je nužda uslijed pojave smanjene sposobnosti ili nemogućnosti profitabilnog poslovanja aktera u privatnom sektoru (vlasništva i najma). Opskrba socijalnim stanovanjem u toj interpretaciji nužno prolazi kroz tri razvojna ciklusa: komodifikacija $\rightarrow$ dekomodifikacija $\rightarrow$ rekomodifikacija. Ukupno gledano, marginalizacija socijalnog stanovanja dugoročno postaje neizbježna sudbina razvijenih kapitalističkih zemalja, pri čemu se navode tri „abnormalna“ razdoblja u 20. stoljeću - početkom stoljeća te poslije dvaju svjetskih ratova - u kojima je implementacija programa masovnog socijalnog stanovanja postala odgovor na „poopćenu društvenu krizu i/ili restrukturiranje kapitalističkih režima“, odnosno „situaciju u kojoj privatno stambeno tržište nije bilo u mogućnosti, zbog raznih razloga, pružiti adekvatna stambena rješenja za dijelove stanovništva“ te „kada su nepodmirene stambene potrebe tih dijelova stanovništva imale širi značaj za društva i gospodarstva unutar kojih su postojale, zbog povećavanja socijalnih tenzija i krize [...] ili zbog ekonomske modernizacije“ (Harloe, 1995.:523-524).

Između generalizacijskih razina jukstapozicijske i konvergencijske analize smještene su divergencijske analize inspirirane Mertonovim (1979.) „teorijama srednjeg dometa“. Divergencijske analize više se oslanjaju na kvalitativne metode istraživanja od suparničkih te su kontekstualno utemeljene, pa se razlike između zemalja objašnjavaju utjecajem kulturnog, političkog i ideološkog naslijeđa na razvoj stambenog sustava uz uvažavanje povijesnih specifičnosti društava u pitanju. Divergencijska 
analiza u komparativnim stambenim studijama umnogome svoju popularnost duguje vezivanju uz istraživanja socijalne politike, točnije teoriju „režima socijalne države“ G. Esping-Andersena. U navedenom djelu Esping-Andersen (1990.) smatra da se „Šire shvaćene“ socijalne države - one s većom ulogom države u upravljanju i organizaciji gospodarstva - komparativnom analizom kvalitete socijalnih prava koja se manifestiraju dekomodifikacijom životnog standarda, oblika socijalne stratifikacije kao uzroka i posljedice socijalnih politika te odnosa tržišta, države i obitelji u pružanju socijalne dobrobiti stanovništvu, grupiraju u tri klastera (liberalni, socijaldemokratski i konzervativno-korporativni), odnosno ideal-tipski konstruirana režima kao produkata konstelacije političke moći kroz (dominantni) utjecaj klasne mobilizacije (radnika), strukture klasno-političkog koaliranja te povijesnog naslijeđa institucionalizacije. Dakle različiti režimi (nezavisna varijabla) proizvode socijalne države (zavisna varijabla): liberalni rezidualne, socijaldemokratski dekomodificirane te konzervativno-korporativni korporativne (Esping-Andersen, 1990.:26-29; usp. Kemeny, 2001.:59). ${ }^{7}$

Jedan od prvih pokušaja primjene Esping-Andersenove teorije na područje stanovanja predstavlja rad Barlowa i Duncana (1994.) o „sustavima stambene opskrbe“ (usp.

7

U socijalnim sustavima liberalnih režima (SAD, Australija, Kanada) socijalna pomoć potrebitima ovisi o provjeri njihovih prihoda i imovine, a dominiraju skromni univerzalni transferi i planovi socijalnog osiguranja. Također, efekt je dekomodifikacije minimalan zbog nepostojanja univerzalnih socijalnih prava, dominantne vrijednosne orijentacije vrijednosti su radne etike liberalizma i protestantizma, a društvo je stratificirano „relativnom jednakošću u siromaštvu među primateljima socijalne pomoći, tržišno razlikovanom dobrobiti među većinskim stanovništvom te klasno-političkim dualizmom među njima“ (Esping-Andersen, 1990.:27). Socijalni sustavi konzervativno-korporativnih režima (Austrija, Francuska, Njemačka i Italija) predstavljaju svojevrsnu reinkarnaciju korporativizma u postindustrijskom dobu, a temelje se na očuvanju socijalnih statusa kao osnove razlikovanja klasa i grupa u društvu. Socijalna prava uglavnom su vezana uz radni status, pa su širi dekomodifikacijski i redistributivni utjecaji politika zanemarivi, a uloga privatnog osiguranja minimalna. Također, postoji značajan utjecaj crkve i tradicionalnih obiteljskih vrijednosti, zbog čega se taj režim ponekad naziva i familističkim. Tako se, primjerice, iz programa socijalnog osiguranja isključuje supruge koje ne rade, a obiteljske naknade potiču majčinstvo, dok su usluge skrbi za djecu nerazvijene, što odgovara poštivanju (katoličkog) načela supsidijarnosti. Socijalnim sustavima socijaldemokratskog režima (Švedska, Danska, Norveška) svojstveni su dekomodifikacijski univerzalizam socijalnih prava i emancipacijsko promicanje jednakosti, $s$ jedinstvenim sustavom osiguranja za radničku i srednju klasu. Tržišno induciran dualizam liberalnog i statusno-subsidijarna priroda državnog intervencionizma u zemljama korporativnog režima ne postoje u socijaldemokratskom režimu, u kojem „svi profitiraju, svi su ovisni i svi se osjećaju prozvanima platiti“ (Esping-Andersen, 1990.:28), a temeljna "fuzija dobrobiti i rada“ podrazumijeva privrženost ostvarenju pune zaposlenosti, povećanju individualne samostalnosti svakog pojedinca neovisno o obiteljskoj situaciji te pomoći obiteljima pri suočavanju sa socijalnim rizicima. Polovinom 1990-ih javlja se prvi val kritika Esping-Andersenove tipologije, među kojima se istaknuo napor istraživača socijalne politike pri dodavanju izvornoj tročlanoj podjeli i četvrti model južnoeuropskih „mediteranskih“ socijalnih režima (Ferrera, 1996.), čija su temeljna obilježja socijalni klijentelizam, nerazvijenost socijalne države te „familizam“, odnosno dominacija (proširene) obitelji kao izvora dobrobiti svakog pojedinca nasuprot tržištu, državi i neprofitnom sektoru. 
Ball, 1983.) u Francuskoj, Švedskoj i Ujedinjenom Kraljevstvu. Liberalnim režimima svojstvena je otvorena intervencija ograničena na stigmatiziranu opskrbu za rezidualnu populaciju u nemogućnosti adekvatnog sudjelovanja na tržištu rada, skrivene potpore za dobrostojeće (uglavnom vlasnike stanova), državne politike koje favoriziraju tržište (velike građevinske firme i kreditne institucije) te državna intervencija usmjerena k potrošnji, a ne proizvodnji. U korporativnom režimu, manje „ideološki simbolična“ široka otvorena državna potpora ne narušava socijalnu diferencijaciju te je korištena za rješavanje trenutačnih socijalnih problema. Samoopskrba se favorizira zbog izbjegavanja povećanja javnog sektora, a državna intervencija također je usmjerena na potrošnju, a ne proizvodnju. U socijaldemokratskom se režimu na najamno i kooperativno stanovanje gleda kao na alternativni sektor otvoren svima, razvojni profit smatra se nezasluženim te postoji snažna intervencija u stambenoj proizvodnji. Konačno, u rudimentarnom (mediteranskom) režimu postoji slaba tradicija izravnog uplitanja države u stambenu opskrbu, dok je samoopskrba zasnovana na proširenoj obitelji zamjena za ulogu države (Barlow i Duncan, 1994.:30-31; usp. Allen i sur., 2004.).

Kemenyev (1981., 1992., 1995., 2001., 2004.) višedesetljetni istraživački rad polazi od uočenih osnovnih razlika među stambenim statusima razvijenih zemalja prema kriteriju omjera vlasništva i nevlasništva (najma) nad objektom stanovanja. Kemeny (1992.) smatra da je stambena politika vrlo važan dio socijalne politike, posebice u odnosu na institucionalne aranžmane temeljene na vezi stanovanja i socijalne države. Negativna korelacija između veličine udjela privatnog vlasništva nad stanovima u nacionalnoj strukturi stambenih statusa te socijalnih troškova države zapravo je odraz dominacije različitih društvenih ideologija (Kemeny, 1981., 1992.). Pod pretpostavkom da stanovnici razvijenih zemalja pokazuju relativnu vrijednosno-orijentacijsku (ideološku) homogenost što se tiče uloge stambenog vlasništva u životu svakog pojedinca, ocrtava se temeljna podjela stambenih sustava na anglosaksonske zemlje pod utjecajem „privatističke“ (engl. privatism) ideologije, u kojima je individualizirano stambeno zbrinjavanje norma uz postojanje manjka javne potpore za redistributivne kolektivne aranžmane socijalne sigurnosti, te „kolektivističke“ (engl. collectivism) ideologije kontinentalnih europskih zemalja, u kojima je situacija obrnuta. Naknadno, potaknut tipologijom režima socijalnih država (Esping-Andersen, 1990.), odnosno njezinom kritikom, Kemeny (1995.; usp. Hoekstra, 2010.) konstruira sustave stambenog najma na dualne i unitarne. Dualni (privatistički) sustavi anglosaksonskih zemalja (Velika Britanija, Australija i Novi Zeland) prema toj podjeli čine dio šireg socijalnog sustava niske razine državne potrošnje na socijalne usluge i transfere te visokog udjela vlasništva nad stanovima u strukturi stambenih statusa, dok su njihove „policy strategije“ tržišne. Razvijeno hipotekarno tržište te tržište nekretnina i privatnog najma primarni su izvori stambenog zbrinjavanja kućanstava, dok je ukupni udio socijalnog stanovanja i neprofitnog sektora u strukturi stambenih statusa marginalan. Usluge stigmatiziranog državnog sektora socijalnog najma i neprofitnog stambenog sektora usmjerene su isključivo na najpotrebitije članove društva, uz obveznu proceduru provjere njihovih prihoda i imovine (engl. meanstest). Paradoksalno, državni intervencionizam u dualnim (tržišnim) sustavima efektivno štiti slobodno privatno tržište najma od konkurencije zbog prisutnosti nejednakog regulativnog tretmana. Unitarni (kolektivistički) sustav svojstven je europskim 
kontinentalnim zemljama (Švedska, Njemačka, Švicarska, Nizozemska) s visokim razinama javne potrošnje na socijalne usluge i transfere i manjim, ali varijabilnim udjelom vlasništva nad stanovima u strukturi stambenih statusa i komandnim „policy strategijama“. U unitarnim su sustavima „privatni najamni i socijalni stanovi podvrgnuti sličnoj regulaciji, imaju više ili manje iznose najma i natječu se međusobno na jedinstvenom tržištu“ (Hoekstra, 2010.:14). Na taj se način uravnotežuju razine iznosa najma u profitnom (tržišnom) i neprofitnom (državnom i civilnom) sektoru i pruža izvor visokog standarda stanovanja u uvjetima sigurnog stambenog statusa (Kemeny, 1995.:4).

Posljednju i ujedno za ovaj rad najvažniju divergencijsku teoriju predstavlja tipologija „vrsta rezidencijalnog kapitalizma“ (Schwartz i Seabrooke, 2009.). Uz pretpostavku da je stanovanje najveća imovina velikom dijelu stanovništva te najveća financijska imovina u većini gospodarstava, indikatori rezidencijalnog vlasništva (stanovi, kuće) i vezanog hipotekarnog duga u doba su „financijalizacije“, odnosno „povećanja važnosti financijskih tržišta, motiva, institucija i elita u djelovanjima gospodarstva i institucija koje njime upravljaju, jednako na nacionalnoj kao i na međunarodnoj razini“ (Epstein, 2005.:3) najbolji pokazatelji razlika među stambenim sustavima razvijenih država te ujedno odgovaraju postavkama teorije „vrsta kapitalizma“ (Hall i Soskice, 2001.), Kemenyevim „sustavima najma“ i Esping-Andersenovim (1990.) dimenzijama dekomodifikacije i stratifikacije. Od 19 zemalja OECD-a u razdoblju 1992. - 2002. korištenih pri usporedbi u tipologiji „vrsta rezidencijalnog kapitalizma“ 13 država članice su EU-a, pa će se time ujedno smatrati i najrazvijenijima ${ }^{8}$ u vlastitoj skupini, koju čini ukupno 28 država članica EU-a. To su: Danska, Nizozemska, Njemačka, Ujedinjeno Kraljevstvo, Švedska, Finska, Francuska, Austrija, Belgija, Irska, Portugal, Španjolska, Italija. Prema prije spomenutim dimenzijama, vremenskom razdoblju te globalnom uzorku sačinjena je četveročlana tipologija stambenih sustava: korporativistički, državno-razvojni, liberalni i familistički (tablica 1.). Tipologija „vrsta rezidencijalnog kapitalizma“ poslužit će kao svojevrsna sinteza prije spomenutih teorija divergencije stambenih sustava, dok će se na spomenutom uzorku razvijenih zemalja EU-a temeljiti daljnja analiza konvergencijskih trendova.

8 Temeljni kriteriji razvijenosti država predmet su dugogodišnjih prijepora stručnjaka. Ipak, u ovom se radu zastupa jednostavna argumentacija za potkrijepu kriterija odabira: ukoliko su, prema Schwartzu i Seabrookeu (2009.), nabrojane države EU-a svrstane u zemlje OECD-a (koje prema svojoj definiciji čine skupinu najrazvijenijih država svijeta), te su države EU de facto razvijenije od ostalih 15 država skupine EU-28, pa ih se naziva „razvijenim“ nasuprot onima „u razvoju“ (primjerice tranzicijske države). 
Tablica 1.

Tipologija vrsta rezidencijalnog kapitalizma

\begin{tabular}{|c|c|c|c|}
\hline & \multicolumn{2}{|c|}{$\begin{array}{l}\text { Udio vlasnika stanova - prosjek u razdoblju 1992. - } 2002 \text {. } \\
\text { (odražava veličinu socijalnog najamnog sektora i prema tome komodifikaciju; } \\
\text { djelomično isključenje iz globalnih tržišta kapitala kao posljedica) }\end{array}$} \\
\hline & & Nizak & Visok \\
\hline \multirow{2}{*}{$\begin{array}{l}\text { Postotni udio } \\
\text { hipoteka u } \\
\text { BDP-u - prosjek u } \\
\text { razdoblju 1992. - } \\
\text { 2002. } \\
\text { (odražava } \\
\text { sekuritizaciju } \\
\text { kao uzrok i } \\
\text { stratifikaciju kao } \\
\text { posljedicu, ali } \\
\text { također snažniju } \\
\text { povezanost } \\
\text { s globalnim } \\
\text { financijskim } \\
\text { tržištima) }\end{array}$} & $\begin{array}{l}\text { 음 } \\
\stackrel{n}{5}\end{array}$ & $\begin{array}{l}\text { Korporativistički } \\
\text { Stanovanje (ali ne stanovi) kao } \\
\text { socijalno pravo, snažna tř̌išna } \\
\text { stratifikacija: vlasnici vs. najmoprimci, } \\
\text { plus defamilijalizacija, plus javne } \\
\text { organizacije kontroliraju najamno } \\
\text { stanovanje, niski prihodi od } \\
\text { oporezivanja imovine. Problemi } \\
\text { međugeneracijske jednakosti jer je } \\
\text { outsiderima stanovanje na stambenom } \\
\text { tržištu nepriuštivo. } \\
\text { Hipoteke BDP: } 58,3 \% \\
\text { Udio vlasnika stanova: } 47,0 \% \\
\text { Socijalni najamni sektor: } 20,7 \% \\
\text { Države: Danska, Nizozemska, } \\
\text { Njemačka }\end{array}$ & $\begin{array}{l}\text { Liberalni } \\
\text { Visoko komodificirano, stanovi kao } \\
\text { imovina, snažna tržišna stratifikacija, } \\
\text { vlasnici vs. najmoprimci. Samopomoć } \\
\text { bazirana na tržištu. Visoki prihodi } \\
\text { od oporezivanja imovine. Problemi } \\
\text { međugeneracijske jednakosti jer je } \\
\text { outsiderima stanovanje na stambenom } \\
\text { tržištu nepriuštivo. } \\
\text { Hipoteke BDP: } 48,5 \% \\
\text { Udio vlasnika stanova: } 70,1 \% \\
\text { Socijalni najamni sektor: } 9,4 \% \\
\text { Države: Ujedinjeno Kraljevstvo, SAD, } \\
\text { Kanada, Novi Zeland, Norveška, } \\
\text { Australija }\end{array}$ \\
\hline & $\begin{array}{l}\frac{\text { D }}{N} \\
\stackrel{N}{Z}\end{array}$ & $\begin{array}{l}\text { Državno-razvojni } \\
\text { Stanovanje (ali ne stanovi) kao } \\
\text { socijalno pravo, ali financijska } \\
\text { represija smanjuje tržišnu } \\
\text { segmentaciju/stratifikaciju; plus } \\
\text { privatne organizacije kontroliraju } \\
\text { najamno stanovanje. Niski prihodi od } \\
\text { oporezivanja imovine. } \\
\text { Hipoteke BDP: } 28,2 \% \\
\text { Udio vlasnika stanova: } 58,3 \% \\
\text { Socijalni najamni sektor: } 16,8 \% \\
\text { Države: Švedska, Finska, Francuska, } \\
\text { Austrija, Japan }\end{array}$ & $\begin{array}{l}\text { Familistički } \\
\text { Nekomodificirano, ali ne i } \\
\text { dekomodificirano: Stanovi kao } \\
\text { obiteljsko socijalno dobro, ali ne i } \\
\text { kao socijalno pravo. Stratifikacija } \\
\text { zbog pristupa formalnom sektoru } \\
\text { zapošljavanja. Netržišna samopomoć. } \\
\text { Niski prihodi od oporezivanja } \\
\text { imovine. } \\
\text { Hipoteke BDP: } 21,6 \% \\
\text { Udio vlasnika stanova: } 75,5 \% \\
\text { Socijalni najamni sektor: } 5,5 \% \\
\text { Zemlje: Belgija, Irska, Portugal, } \\
\text { Španjolska, Italija }\end{array}$ \\
\hline
\end{tabular}

Izvor: Schwartz i Seabrooke, 2009.:9, 10, 23.

Ukoliko se smanji uzorak, uključi samo države članice EU-a i upotrijebi način analize svojstven Eurostatu, uočava se nezanemariva korespondencija trenutačnih podataka s onima iz tipologije „vrsta rezidencijalnog kapitalizma“, unatoč dvanaestogodišnjem protoku vremena (grafikon 1.). Stupanj i karakter promjena objašnjavaju se u sljedećem dijelu. 
Grafikon 1.

Postotna distribucija populacije prema stambenom statusu, 2014.

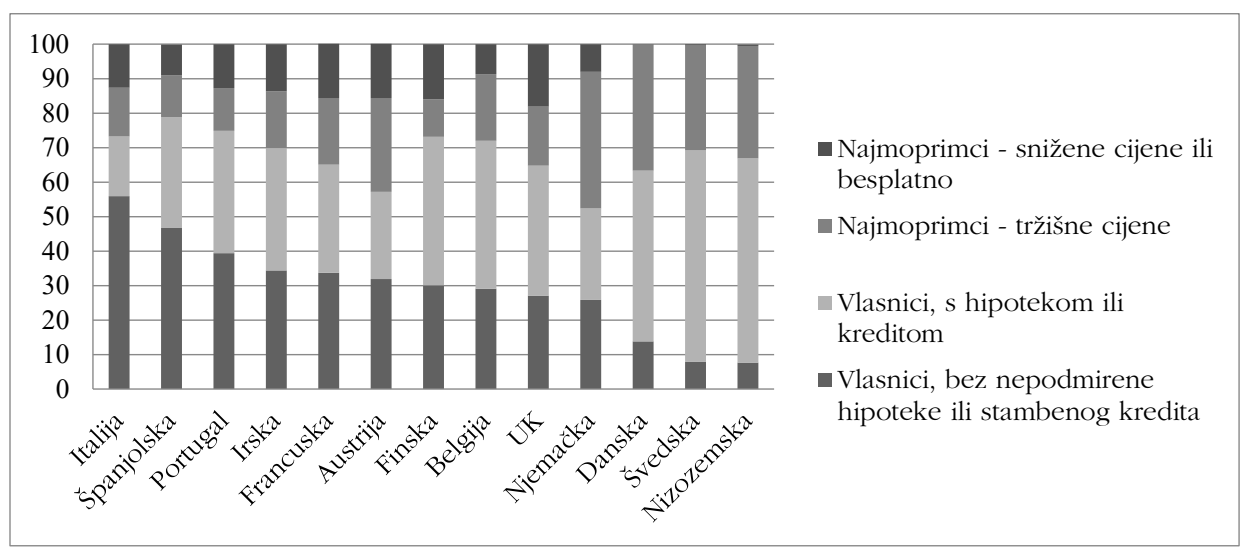

Izvor: Eurostat, 2016.

\section{Trendovi stambene konvergencije u Europskoj uniji}

U prethodnom su dijelu predstavljene temeljne razlike među stambenim sustavima razvijenih država EU-a i njihova tipologizacija, odnosno divergencija. Istodobno se u navedenim zemljama od početka 1990-ih odvijaju dva konvergencijska trenda, koja su usko vezana uz sadašnju konstelaciju stambenih sustava: liberalizacija ${ }^{9}$ i europeizacija. Liberalizacija kao opći konvergentni trend u razvoju stanovanja europskih država bit će iskazana korištenjem međusobno povezanih indikatora: komodifikacija stanovanja izražena porastom udjela vlasništva nad stanovima u strukturi stambenih statusa i financijalizacija stanovanja. Nadalje, financijalizacija će biti iskazana korištenjem dvaju indikatora: porastom rezidencijalnog omjera hipotekarnog duga prema BDP-u te porastom izdavanja volumena sekuritizacije ${ }^{10}$. Konvergencijski trend europeizacije stanovanja bit će prikazan analizom razvoja jedinstvenog tržišta kohezijske politike EU-a, policy okvira integriranog održivog urbanog razvoja i prava na stan.

9 Liberalizaciju je potrebno shvatiti doslovno kao oslobađanje od državne regulacije stambenih statusa i financijskog sektora.

10 Riječ je o „stvaranju nove financijske imovine kombiniranjem druge slične imovine, od hipoteka do tantijema, te prodaje iste investitorima u novom obliku pogodnom za trgovinu“ (Briscoe i Fuller, 2007.:288). 


\subsection{Liberalizacija}

\subsubsection{Komodifikacija stanovanja}

Udio vlasništva nad stanovima u strukturi stambenih statusa od kraja Drugog svjetskog rata do 1990-ih značajno je porastao u većini država OECD-a, pri čemu se ističu europske države, točnije Belgija, Irska, Italija, Nizozemska, Norveška, Portugal, Španjolska i Ujedinjeno Kraljevstvo, s porastom stope vlasništva nad stanovima od preko 15 postotnih bodova tijekom druge polovine prošlog stoljeća (Atterhog, 2006.). Taj je konvergencijski trend, koji se naziva komodifikacijom stanovanja, uz neke iznimke kao što je Njemačka, nastavljen do danas (tablica 2.).

Tablica 2.

Poratni rast privatnog vlasništva kućanstava nad stanovima u odabranim zemljama EU-a (u \% stambenog fonda)

\begin{tabular}{|c|c|c|c|c|c|}
\hline Države EU-a & $\mathbf{1 9 7 0 .}$ & $\mathbf{1 9 8 0 .}$ & $\mathbf{1 9 9 0 .}$ & 2002. & 2011./2012. \\
\hline Austrija & 41 & 48 & 55 & 56 & 57 \\
\hline Belgija & 55 & 59 & 67 & 71 & 78 \\
\hline Francuska & 45 & 51 & 54 & 55 & 58 \\
\hline Njemačka & $/$ & $/$ & 38 & 53 & 56 \\
\hline Nizozemska & 35 & 42 & 44 & 51 & 54 \\
\hline Danska & 49 & 52 & 51 & 58 & $74^{*}$ \\
\hline Finska & 59 & 61 & 67 & 42 & $66^{*}$ \\
\hline Švedska & 35 & 41 & 42 & 80 & 80 \\
\hline Italija & 50 & 59 & 67 & 64 & 75 \\
\hline Portugal & $/$ & 57 & 58 & 85 & 85 \\
\hline Španjolska & 64 & 73 & 76 & 77 & 75 \\
\hline Irska & 71 & 76 & 81 & 69 & 66 \\
\hline UK & 49 & 56 & 68 & & 53 \\
\hline
\end{tabular}

*Uključujući kooperativno stanovanje.

Izvor: Horsewood i Dol, 2013. Napomena: desetljeća su zaokružena.

Uzroci su komodifikacije stanovanja brojni, a uključuju povlačenje države iz promocije socijalnog stanovanja, poticanje vlasničkog statusa, privatizaciju fonda socijalnog stanovanja, odmak od izravnih stambenih subvencija (ponuda) prema neizravnima (potražnja) i drugo (Arbaci, 2007.:406). Među najistaknutijim uzrocima tog trenda Ronald (2008.) daje eksplanatornu prednost tzv. „ideologiji kućevlasništva“ (engl. ideology of homeownership), kojom implicira da „prakse stambenih statusa nisu benigne, već podržavaju posebno opredjeljivanje ili interakciju odnosa moći i društva" (str. ix). Drugim riječima, ta se socijalno-ideološka konstrukcija manifestira kao pokušaj izgradnje „kućevlasničkog društva“ ili „kućevlasničkih demokracija" (Ferguson, 2014.) političkom podrškom pribavljanju privatnog vlasništva nad objektom stanovanja (kuća, stan i dr.) za svako kućanstvo. Ideologija kućevlasništva prisutna je od kraja 1970-ih, što vremenski korespondira s fiskalnom krizom razvi- 
jenih socijalnih država u Europi (Esping-Andersen, 1999.) $)^{11}$ i erom neoliberalizma (Przeworski, 1986.). Kućanstva postaju stambeni potrošači, odnosno maksimizatori stambene dobrobiti, koji su individualizirali socijalne rizike stambenim vlasništvom. U prvom dijelu rada pokazane su razlike u stambenim statusima i ideologijama europskih zemalja, ali je ova svojevrsna „posesivno-individualistička“ (MacPherson, 1981.) ideja poželjnosti vlasništva nad nekretninom - kao odraza pozitivnih vrijednosti, primjerice marljivosti, štedljivosti, samostalnosti i izbora - bila prihvaćena u svim razvijenim zemljama, iako s različitom snagom (Ronald, 2008.).

\subsubsection{Financijalizacija stanovanja}

Konzervativno shvaćanje stana kao „skloništa“ pribavljenog tijekom radnog vijeka od 1970-ih u razvijenom svijetu, posebice SAD-u, ustupa mjesto shvaćanju stana kao stambene imovine, koja je s vremenom postala dominantni oblik bogatstva svakog kućanstva u razvijenim zemljama. Proliferacijom ponude usluga privatnih financijskih institucija nekretnine je postalo moguće likvidirati u svrhu eventualne zaštite gubitka prihoda od rada uslijed povećanja konkurentnosti i nesigurnosti na tržištu rada.

Rastom udjela vlasnika u strukturi stambenih statusa i dostupnošću (re)kreditiranja stambene nekretnine komodificirano stanovanje postaje utjecajan ulog na financijskim tržištima, a stambene nekretnine smatra se i legitimnim oblikom nacionalnog bogatstva, odnosno kapitala (Piketty, 2014.:56-59). Prema Aalbersu (2016.:3), mehanizam financijalizacije stanovanja javlja se u nekoliko oblika: sekuritizacija ${ }^{12}$ hipotekarnih kredita; rast subprime ${ }^{13}$ i predatorskog pozajmljivanja, rastući hipotekarni dug kućanstava; ulazak privatnih dioničkih društava, hedge fondova ${ }^{14}$ i javno

11 Kriza socijalne države iz 1970-ih proizvela je i stambenu krizu zbog smanjenja uloge države u stambenom zbrinjavanju. Jedan od najpoznatijih političkih poteza definitivno je onaj britanske premijerke M. Thatcher pri izglasavanju Zakona o pravu na kupnju (engl. Right to Buy Act) 1980. (usp. King, 2016.:20-21). Milijun i pol općinskih stanova (engl. council flats) prešlo je u privatno vlasništvo, što se pokazalo korisnim sredstvom „širenja kapitalističke baze" (Ferguson, 2014.), odnosno glasačke baze konzervativnih stranaka, kojima je stambena politika orijentirana prema promociji vlasništva. Također, privatizacija je temeljna strategija u provođenju mjera štednje, smanjujući javnu potrošnju, a istodobno puneći državni proračun kapitalom od prodaje.

12 Prema Reinhart i Rogoffu (2011.:404), „sekuritizacija hipoteka uključuje skupljanje i ponovno pakiranje udruženih hipoteka u svrhu transformacije visoko idiosinkrastičnih pojedinačnih kredita u standardiziranije proizvode“. Usporedi s fusnotom br. 10. Također, skraćena definicija nalazi se u nastavku teksta.

13 Ponajbolji je hrvatski prijevod te riječi „drugorazredni“ (Ferguson, 2014.:237). Drugorazredni krediti nazivani su i „lošim“ i „jako rizičnim“, a podrazumijevaju „hipoteke koje podižu obitelji za koje je gotovo sigurno da neće moći otplaćivati kad prođe početna faza s niskom kamatom" (Varoufakis, 2014.:119).

14 Riječ je o investicijskim fondovima za upravljanje rizikom koji se koriste metodom „omedivanja“ (engl. hedging), odnosno „izbjegavanja ili umanjenja rizika“ (Ferguson, 2014.:202). Detaljnije vidjeti u: Blyth, 2013.:31-32. 
izlistanih građevinskih firmi na subvencionirana tržišta najma te, konačno, oslanjanje neprofitnih stambenih organizacija na obveznice socijalnog stanovanja i komplicirane financijske derivate.

Za razliku od pojednostavljenog prikaza kod Schwartza i Seabrookea (2009.) te opširnog prikaza oblika financijalizacije u Aalbersa (2016.), rast udjela privatnog vlasništva nad stanovanjem u strukturi stambenih statusa - posebice od početka 2000ih - u ovom se radu dominantno veže uz rast stambenog zaduživanja (grafikon 2.) i povećanje volumena izdavanja sekuritizacije (grafikon 3.) kao najvažnijih indikatora financijalizacije stanovanja.

\section{Grafikon 2.}

Rezidencijalni omjer hipotekarnog duga prema BDP-u po stambenim sustavima, 2001. - 2013. (godišnje prosječne vrijednosti izražene u \%)

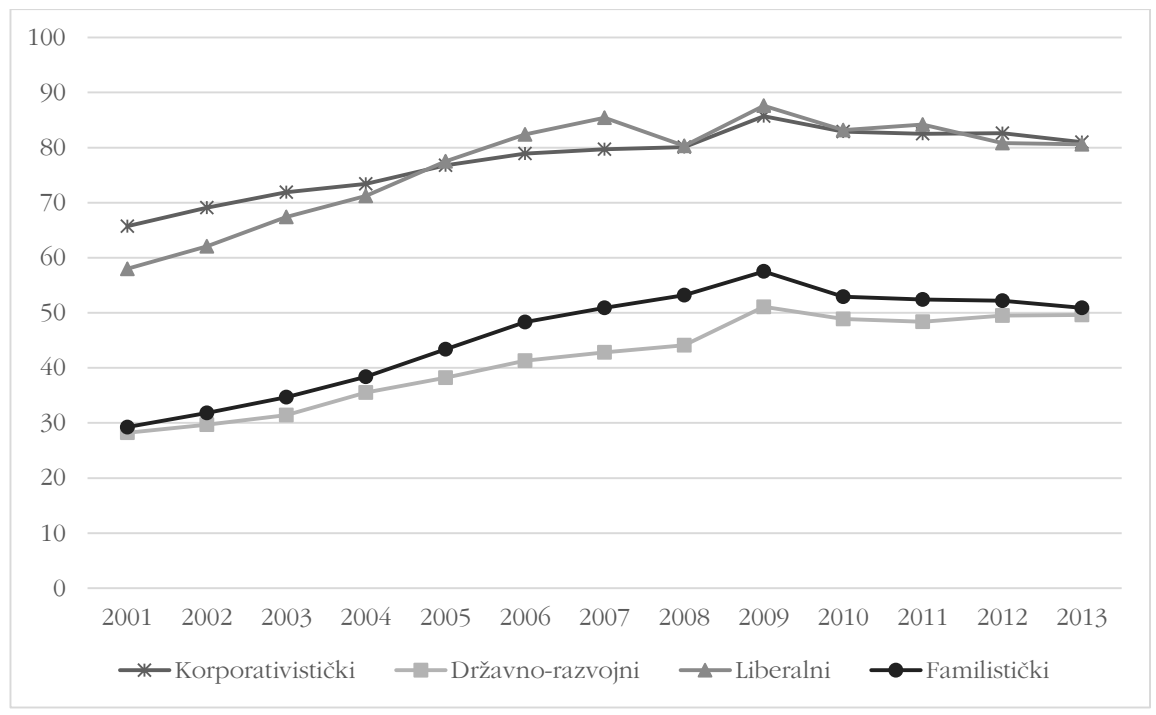

Izvor: Izračun autora prema podacima Hypostata (2016.). ${ }^{15}$

Dewilde (2016.:3-4) objašnjava logiku u pozadini veze dereguliranog financijskog sektora, zaduživanja, vlasništva nad nekretninom i cijena nekretnina: „U nekoliko zemalja banke su ušle na strana tržišta hipotekarnog zajma kroz sekuritizaciju skupljanje manje rizičnih i rizičnih hipoteka u investicijske proizvode. Kako je rasla potražnja za takvim proizvodima, hipotekarni rizici su prebačeni na investitore, dok je izdavanje hipotekarnih zajmova postao posao posrednika, čiji je glavni poticaj prodati više (subprime) hipoteka. Precijenjeno stanovanje služilo je kao jamstvo daljnjem zaduživanju [...]. Potražnja za hipotekarnim zaduživanjem i kreditiranjem,

15 Države su smještene u klastere sukladno tablici 1. u svrhu jednostavnijeg prikaza trenda. Također, ograničavanjem izvornog OECD-ovog uzorka iz studije Schwartza i Seabrookea (2009.) na države EU-a, Ujedinjeno Kraljevstvo samostalno predstavlja liberalni stambeni sustav. Ova napomena vrijedi i za grafikon 4. 
vlasništvo nad nekretninom i cijene nekretnina tako su nastavili rasti, vodeći do spekulativnih balona u SAD-u, Irskoj, Španjolskoj, Portugalu i Ujedinjenom Kraljevstvu. [...] Sekuritizacija hipoteka, povlačenje kapitala i refinanciranje su zabranjeni u nekoliko zemalja (Francuska, Austrija, Belgija, Njemačka); cijene stanova i hipotekarni dugovi u ovim zemljama su porasli mnogo manje u odnosu na zemlje s manje rigidnim regulatornim pristupom“.

\section{Grafikon 3.}

Godišnje izdavanje sekuritizacije u Europi, 2000. - 2014. (u milijardama eura) ${ }^{16}$

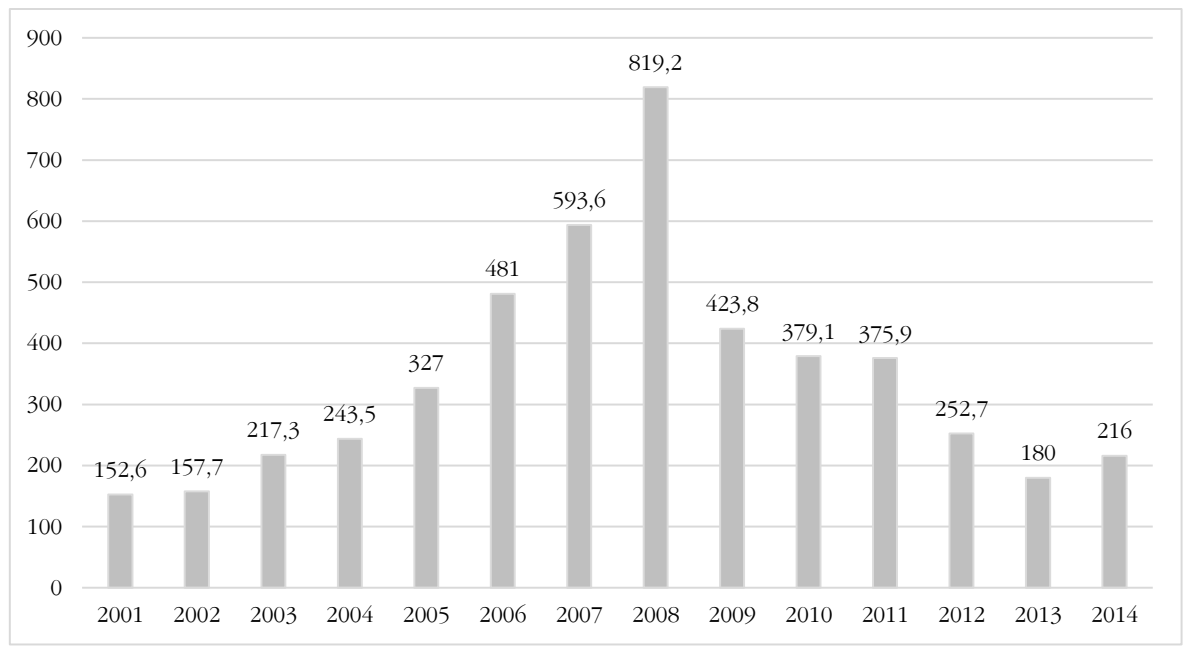

Izvor: podaci prilagođeni iz prikaza Kraemer-Eis i sur., 2015.:14.

Rast cijena nekretnina (grafikon 4.) svojstven je razdoblju trenda financijalizacije. Nekretninski balon koji je prethodio krizi prozvan je najvećim u povijesti, s procjenom da je „porasla cijena rezidencijalnih objekata s 40 trilijuna na 70 trilijuna u razdoblju 2000. - 2005.“, a „prosječni udio vlasništva nad stanom u EU-u dosegao je 64\%, i stambena imovina čini više od 40\% ukupnog BDP-a. U isto vrijeme, hipotekarni dug se utrostručio u jednom desetljeću, postavši jednak trećini BDP-a EU-a" (Ronald, 2008.:3-4). Ta „toksična veza“ (Ferguson, 2014.) stanovanja i financijskih tržišta, koja je u sedmogodišnjem razdoblju do 2008. drastično uznapredovala, kasnije se manifestira kao jedan od okidača globalne financijske krize iz 2008. godine. Štoviše, rast

16 Ovakav način prikaza podataka nije primjeren komparativnim studijama zbog nemogućnosti diferencijacije zemalja korištenih u uzorku. Ipak, u nedostatku kvalitetnijeg načina prikaza podataka o izdavanju sekuritizacije, ovakvom načinu pribjegavaju čak i najpoznatiji autori iz ovog područja (usp. Aalbers, 2009.) jer su im (kao i autoru ovog rada) nedostupni precizniji podaci. Sumarni prikaz uglavnom se odnosi se na Francusku, Ujedinjeno Kraljevstvo, Španjolsku, Nizozemsku, Italiju i Njemačku jer spomenute zemlje čine približno 90\% udjela ukupnog izdavanja sekuritizacije u EU-u. Funkcija takvog pojednostavljenog prikaza trenda sekuritizacije ilustrativna je, a ne analitička. Za jedan dodatni (također nepotpuni) izvor podataka o većem broju država (Belgija, Francuska, Njemačka, Irska, Italija, Nizozemska, Portugal, Španjolska, UK) vidjeti: SIFMA, 2016. 
cijena nekretnina pokazao se najboljim indikatorom nadolazeće bankarske i tečajne krize (Reinhart i Roggof, 2011.:280).

\section{Grafikon 4.}

Prosječne vrijednosti indeksa realnih cijena stanova prema stambenim sustavima, 2000. - 2015. (2000 = 100)

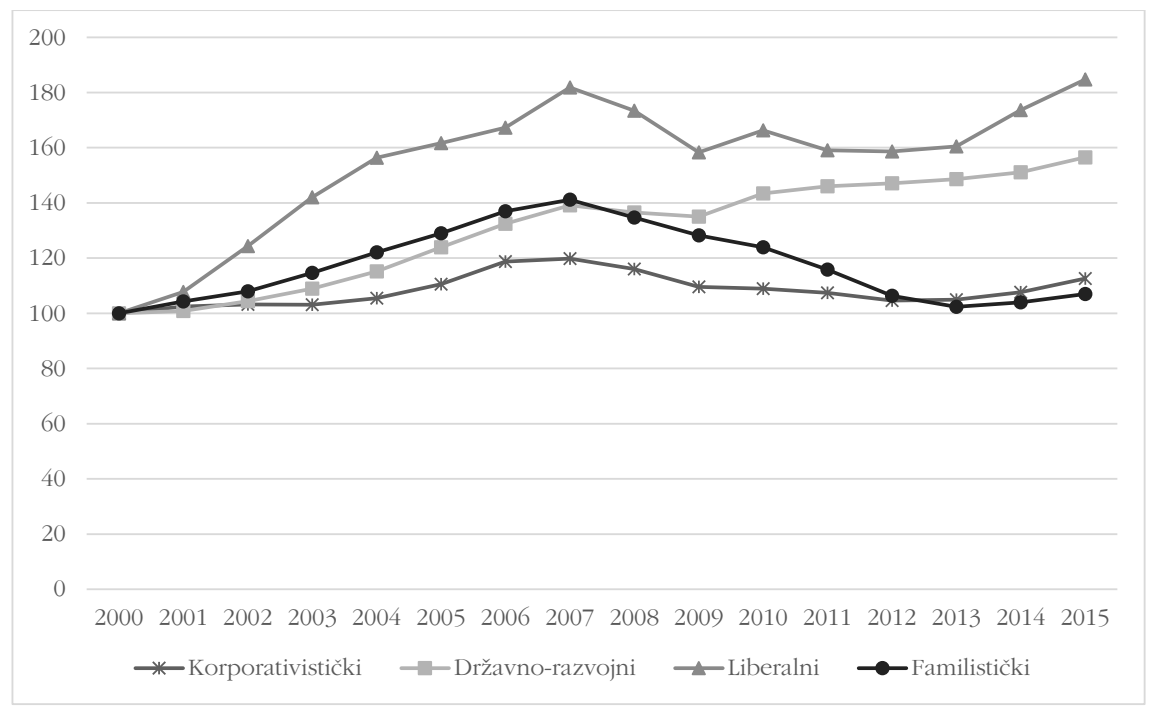

Izvor: Izračun autora prema podacima OECD-a (2016.b).

\subsection{Europeizacija}

Postojanje različitih definicija europeizacije ukazuje na važnost, ali i višeznačnost tog procesa. Jedna je od najpoznatijih i najobuhvatnijih Raedellijeva (2004.:3), a definira je kao skup procesa: a) konstrukcije, b) difuzije i c) institucionalizacije formalnih i neformalnih pravila, procedura, političkih paradigmi, stilova, „načina na koji se rade stvari" te zajedničkih vrijednosti i normi, koje se prvo definiraju i konsolidiraju unutar procesa donošenja odluka na razini EU-a te potom inkorporiraju u logiku domaćeg diskursa (nacionalnog, subnacionalnog), identitete, političke strukture i javne politike.

Tipologijom „europeizacijskih mehanizama“ institucionalne promjene Knill i Lehmkuhl (1999.) pokušali su pojednostavniti i precizirati objašnjenje različitih tipova europeizacije domaće politike. Pozitiona integracija podrazumijeva propisivanje „pozitivnog“ institucionalnog modela s kojim se države članice trebaju uskladiti te potiče promjenu politika na najeksplicitniji način. Većinom se odnosi na strategije suočavanja s „tržišnim neuspjesima“ (engl. market failures), kao što su politike zaštite okoliša. Ipak, zbog poštivanja načela supsidijarnosti u području stambene politike, ne može biti riječi o mehanizmu pozitivne integracije; nepostojanje nove 
regulatorne politike uvjetuje nemogućnost sačinjavanja institucionalnog modela za domaću suglasnost. Naglasak je potrebno staviti mehanizme negativne (tržišne) i posebno „uokviravajuće“ (kognitivne) integracije.

\subsubsection{Negativna integracija - jedinstveno tržište i kohezivni razvoj}

Negativnom integracijom na implicitni se način promjene politika postižu promjenom domaćih oportunitetnih struktura, odnosno postojećih aranžmana distribucije moći i resursa europskim zakonodavstvom. Odnosi se na strategije „osnaživanja tržišta“ (engl. market enhancement), kao što su stvaranje i liberalizacija zajedničkog europskog tržišta. Primjerice u građevinskom sektoru događaju se ključne promjene: slobodnijim kretanjem roba (građevinski materijal) i radne snage (radne migracije) te kapitala (liberalizacija tržišta nekretnina) mijenjaju se domaće oportunitetne strukture, čime se utječe na stupanj redistribucije moći i resursa među domaćim akterima.

Europska je integracija, pod egidom stvaranja integriranog tržišta prvotnim usvajanjem Jedinstvenog europskog akta 1986. godine te napretka prema ekonomskoj i monetarnoj uniji, postala sinonim za konvergencijski proces, koji se odrazio i na stanovanje, točnije stambenu politiku europskih zemalja jer su 1990-ih zbog „monetarističke gospodarske politike proračuni za stambenu politiku srezani, subvencije postale izrazito ciljane, dok su stambene financije unificirane" (Matznetter, 2006.:8). Procjena pozitivnog utjecaja jedinstvenog tržišta EU-a na nacionalna gospodarstva različitih zemalja EU-a varira između 3 - 10\% BDP-a, dok za većinu iznosi između 5 - 6\% (McCann, 2015.:5). Strukturni razvojni fondovi EU-a ${ }^{17}$ djeluju simultano s napretkom jedinstvenog tržišta zbog nužnosti ujednačavanja stupnja razvoja različitih (novih i starih) država članica EU-a, odnosno njihove kohezije (tablica 3.). Kohezija je upisana u same temeljne osnivačke dokumente, kao što je Ugovor o Europskoj uniji (članci 174. i 175.), gdje se pod ulogom EU-a spominje „promocija ekonomske, socijalne i teritorijalne kohezije“, dok „koncept kohezije naglašava

17 Europski socijalni fond (ESF) osnovan je s prvotnom namjerom povećanja mobilnosti radnika i mogućnosti zapošljavanja na zajedničkom europskom tržištu. Trenutna je namjena sredstava Europskog socijalnog fonda povećanje mogućnosti zapošljavanja, jačanje socijalne uključenosti, borba protiv siromaštva, promicanje obrazovanja, vještina i cjeloživotnog učenja te podupiranje održivog razvoja. Iz Kohezijskog fonda (CF) pružaju se financijski doprinosi za ekološke projekte i transeuropske mreže u području prometne infrastrukture. Služi smanjivanju gospodarskih i socijalnih razlika, a od 2007. ovlašten je davati potporu i projektima na područjima povezanima s održivim razvojem, kao što su energetska učinkovitost i obnovljivi izvori energije. Sredstva iz fonda dostupna su samo državama članicama čiji je bruto nacionalni dohodak po stanovniku niži od 90\% od prosjeka EU-a. Osnivanjem Europskog fonda za regionalni razvoj (ERDF) nastojalo se ublažiti razlike u razinama razvoja europskih regija i smanjiti nerazvijenost regija u najnepovoljnijem položaju. Također, sredstvima ERDF-a financira se ublažavanje ekonomskih, socijalnih i ekoloških problema u urbanim područjima (gradovima), s posebnim fokusom na integrirani održivi urbani razvoj (McCormick, 2010.). 
činjenicu da integrirano tržište može biti dugoročno uspješno jedino ako su se svi tržišni sudionici u mogućnosti učinkovito tržišno angažirati na način da je distribucija tržišnih koristi raširena diljem tržišta i da se ne povećava konzistentno samo uskoj skupini tržišnih sudionika, u ovom slučaju država članica, na štetu drugih“ (McCann, 2015.:49).

\section{Tablica 3.}

Financijska sredstva isplaćena odabranim državama članicama EU-a iz strukturnih fondova prema programskim periodima (u eurima) ${ }^{18}$

\begin{tabular}{|c|c|c|}
\hline \multirow{2}{*}{ Države EU-a } & \multicolumn{2}{|c|}{ Programski period } \\
\hline & 2000. - 2006. & 2007. - 2013. \\
\hline Austrija & $1.730 .171 .776,24$ & $782.014 .217,87$ \\
\hline Belgija & $1.989 .162 .836,69$ & $1.204 .476 .095,59$ \\
\hline Danska & $742.609 .741,14$ & $277.275 .740,43$ \\
\hline Finska & $2.080 .122 .753,05$ & $1.050 .909 .150,40$ \\
\hline Francuska & $15.843 .913 .656,14$ & $7.578 .351 .879,26$ \\
\hline Njemačka & $30.121 .734 .108,81$ & $17.570 .552 .148,00$ \\
\hline Irska & $3.159 .209 .962,56$ & $508.155 .947,20$ \\
\hline Italija & $30.245 .346 .113,59$ & $13.535 .892 .900,31$ \\
\hline Nizozemska & $2.768 .110 .985,41$ & $1.023 .197 .648,01$ \\
\hline Portugal & $20.609 .135 .005,95$ & $16.751 .939 .122,28$ \\
\hline Španjolska & $46.801 .881 .177,10$ & $21.413 .535 .306,47$ \\
\hline Švedska & $2.075 .508 .501,19$ & $1.116 .915 .535,65$ \\
\hline UK & $16.719 .006 .047,96$ & $5.576 .582 .435,77$ \\
\hline
\end{tabular}

Izvor: European Commission, 2016. Napomena: period 2000. - 2006. - SF $=$ ERDF + ESF + EAGGF + FIFG; period 2007. $-2013 .-\mathrm{SF}=\mathrm{ERDF}+\mathrm{CF}+\mathrm{ESF}$.

Kohezija nije shvaćena isključivo u smislu „trickle-down“ efekta, kojim bi učinak jedinstvenog tržišta sa slobodnim protokom ljudi, roba, kapitala i usluga trebao značiti ponajprije veće investicije u nerazvijenije zemlje i regije EU-a, a time i sma-

18 Prikaz iz tablice ima ilustrativnu funkciju (usp. s fusnotom br. 16) kako bi se stekla predodžba o količini materijalnog ulaganja u kohezivni razvoj u razvijenim državama EU-a. 
njenje nejednakosti, već i kao aktivni razvojni projekt (usp. McCormick, 2010.:168). Kohezijskom politikom ${ }^{19}$ financiranom iz spomenutih strukturnih fondova europska se integracija materijalno očituje trendom povećanja financijske potpore kohezivnom razvoju, pri čemu je na „strukturne fondove 1984. godine otpadalo samo 18\% proračuna EZ-a [Europske zajednice], a u 2007. godini skoro 45\%“ (McCormick, 2010.:60). Ipak, određivanje uvjeta za ostvarivanje financiranja može se smatrati oblikom negativne integracije jer je svim razvojnim akterima (ponajprije države, a zatim gradovi, organizacije civilnog društva i dr.) omogućena izbornost financiranja i stvoren je natjecateljski kontekst za povlačenje sredstava.

Više od dvije trećine europskog stanovništva stanuje u gradovima. Gradovi su odgovorni za 80\% ukupne energetske potrošnje, ali i za 85\% europskog BDP-a (Soto, 2013.:8). Socijalni i ekološki zahtjevi razvoja uz poboljšanje konkurentnosti na dnevni su red dovele izazove kao što su neplansko širenje predgrađa i raštrkanost, koncentracija siromaštva, nezaposlenosti te socijalne isključenosti u urbanim četvrtima, kolonizacija javnih prostora i drugi. „Integrirani održivi urbani razvoj“ najnovija je složenica kojom se obilježava razvojni pristup gradova sukladan ciljevima Kohezijske politike EU-a, a posebice dokumenta Europa 2020. (Europska komisija, 2010.), iako službena definicija ne postoji. Integrirani održivi urbani razvoj ipak se može definirati kao holistički pristup pozitivnoj kvalitativnoj transformaciji gradova na temelju urbane obnove i planiranja te socijalnog ulaganja, koje se pokušava uskladiti sa zaštitom okoliša poštivanjem načela dobre vladavine. Navođenjem policy okvira moguće je rekonstruirati izvjesni konvergentni trend utjecaja urbane i regionalne politike EU-a na razvoj stanovanja jer je adekvatno stambeno zbrinjavanje posredno (urbana obnova, unaprjeđenje energetske učinkovitosti i dr.) i neposredno (projekti socijalnog stanovanja za marginalizirane skupine, prevencija beskućništva, financiranje neprofitnih stambenih organizacija i dr.) tematski uključeno u integrirani održivi urbani razvoj (usp. Czischke, 2013.). Drugim riječima, postoji mogućnost izbornosti financiranja stambenih programa i projekata u okviru integriranog održivog urbanog razvoja (tablica 4.).

19 McCann (2015.:1,16), sukladno službenim europskim dokumentima i strategijama, pod kohezijskom politikom podrazumijeva regionalnu i urbanu razvojnu politiku EU-a, i to iz razloga jer su razne lokalne, regionalne i urbane inicijative izravno vezane uz „sheme financiranja“ na nadnacionalnoj razini, pa je sukladno tome naziva i „najvećom jedinstvenom politikom u EU-u“. Također, smatra da se svaka rasprava o kohezijskoj politici EU-a treba promatrati u odnosu na krovnu strategiju EU-a, Europa 2020. Europa 2020. (2010.) europska je varijanta razvojne strategije istodobno prisutne u drugim nadnacionalnim kontekstima (SAD, OECD) te predstavlja odmak od sektoralnih (parcijalnih) politika Lisabonske strategije, koja se pokazala ishodišno razočaravajućom (McCann, 2015.:7-8). 
Tablica 4.

Policy geneza integriranog održivog urbanog razvoja ${ }^{20}$

\begin{tabular}{|c|c|c|}
\hline $\begin{array}{l}\text { Početak/ } \\
\text { usvajanje }\end{array}$ & $\begin{array}{l}\text { Temeljni projekti, } \\
\text { programi } i \\
\text { dokumenti }\end{array}$ & Sažet opis \\
\hline 1989. - & Urbani pilot projekti & $\begin{array}{l}\text { Mali projekti financirani od EU-a, pokrenuti u svrhu suočavanja s } \\
\text { urbanim nedostacima europskih gradova. }\end{array}$ \\
\hline 1994. & $\begin{array}{l}\text { Urbana inicijativa } \\
\text { zajednice (URBAN): } \\
\text { I. (1994. - 1999.); } \\
\text { II. (2000. - 2006.). }\end{array}$ & $\begin{array}{l}\text { Širem programu naziva Urbana inicijativa zajednice cilj je bila } \\
\text { primjena spomenutih pilot projekata u raznim gradovima EU-a kako } \\
\text { bi se izradila inovativna strategija urbane politike s većim fokusom } \\
\text { na deprivirane gradske četvrti uz korištenje pristupa integriranog } \\
\text { urbanog razvoja. }\end{array}$ \\
\hline 2000. & $\begin{array}{l}\text { Akcijski program iz } \\
\text { Lillea }\end{array}$ & $\begin{array}{l}\text { Višegodišnji program suradnje u urbanim poslovima u EU-a s ciljem } \\
\text { boljeg prepoznavanja uloge gradova u prostornom planiranju, } \\
\text { poboljšanja građanske participacije, promocije integriranog i } \\
\text { uravnoteženog razvoja, difuzije dobrih praksi i umrežavanja i dr. }\end{array}$ \\
\hline 2002. & $\begin{array}{l}\text { URBACT program: } \\
\text { I. (2002. - 2006.); } \\
\text { II. (2007. - 2013.); } \\
\text { III. (2014. - 2020). }\end{array}$ & $\begin{array}{l}\text { Program za razmjenu iskustava izmedu gradova sudionika prije } \\
\text { spomenutih programa i projekata te za transfer dobrih ideja i praksi } \\
\text { u suočavanju s urbanim izazovima. }\end{array}$ \\
\hline & Bristolski dogovor & Rasprava o izgradnji održivih zajednica diljem Europe. \\
\hline 2005. & Urban Acquis & $\begin{array}{l}\text { Urbana pravna stečevina EU-a za metodološko utemeljenje europskog } \\
\text { pristupa integriranog održivog urbanog razvoja sljedećim načelima: } \\
\text { sinergija poslova, ekonomskog razvoja i kompetitivnosti; zaštita } \\
\text { okoliša; integracija ranjivih skupina; fizička revitalizacija grada. }\end{array}$ \\
\hline 2006. & $\begin{array}{l}\text { Europska stambena } \\
\text { povelja }\end{array}$ & $\begin{array}{l}\text { Usvajanjem Europske stambene povelje Europski parlament pružio } \\
\text { je jedinstveni konceptualni okvir, upute i socijalne imperative za } \\
\text { eventualno sačinjavanje nacionalnih strategija stanovanja; EU daje } \\
\text { smjernice, vlade pojedinih država osiguravaju opći okvir provedbe, a } \\
\text { lokalne vlasti i neprofitne stambene organizacije oblikuju programe } \\
\text { sukladne postojećim potrebama. }\end{array}$ \\
\hline & $\begin{array}{l}\text { Teritorijalna agenda } \\
\text { EU-a }\end{array}$ & Početak integracije teritorijalne kohezije u Kohezijsku politiku EU-a. \\
\hline 2007. & $\begin{array}{l}\text { Leipziška povelja o } \\
\text { održivim europskim } \\
\text { gradovima }\end{array}$ & $\begin{array}{l}\text { Na neformalnom ministarskom sastanku o urbanom razvoju i } \\
\text { teritorijalnoj koheziji, ministri su se obvezali da ce: (1) u svojim } \\
\text { državama započeti političku raspravu o tome kako integrirati načela } \\
\text { i strategiju Leipziške povelje o održivim europskim gradovima u } \\
\text { nacionalne, regionalne i lokalne razvojne politike; (2) koristiti alat } \\
\text { integriranog urbanog razvoja i odgovarajućeg upravljanja u cilju } \\
\text { njegove provedbe te da ce u tu svrhu uspostaviti sve potrebne okvire } \\
\text { na nacionalnoj razini i (3) da ce promicati uspostavu uravnotežene } \\
\text { teritorijalne organizacije temeljene na europskoj policentričnoj } \\
\text { urbanoj strukturi. }\end{array}$ \\
\hline 2008. & Marsejska deklaracija & Rekapitulacija ciljeva Teritorijalne agende i Leipziške povelje. \\
\hline 2010. & $\begin{array}{l}\text { Toledska deklaracija } \\
\text { o urbanom razvoju }\end{array}$ & $\begin{array}{l}\text { Sadrži detaljniju problematizaciju ciljeva strategije Europa } 2020 . \\
\text { vezanih za područje urbane politike, a poseban fokus stavljen je na } \\
\text { sačinjavanje Europske urbane agende, koja bi predstavljala kontinuitet } \\
\text { sukcesivnih programa urbanog razvoja u skladu sa zajedničkom } \\
\text { metodologijom Urban acquisa. }\end{array}$ \\
\hline 2011. & $\begin{array}{l}\text { Teritorijalna agenda } \\
\text { EU-a } 2020 \\
\end{array}$ & $\begin{array}{l}\text { Revidirana teritorijalna agenda koja se usklađuje s ciljevima strategije } \\
\text { Europa } 2020 .\end{array}$ \\
\hline 2016. & $\begin{array}{l}\text { Amsterdamski pakt } \\
\text { / Europska urbana } \\
\text { agenda }\end{array}$ & $\begin{array}{l}\text { Konačni proizvod policy razvoja europeizacije stanovanja u kontekstu } \\
\text { integriranog održivog urbanog razvoja. U stanovanju se određuju } \\
\text { ciljevi priuštivosti, s posebnim fokusom na javno priuštivo stanovanje, } \\
\text { pravila državne pomoći i opću stambenu politiku. }\end{array}$ \\
\hline
\end{tabular}

Izvor: Carpenter, 2013.; Soto, 2013.; navedeni dokumenti - detaljnije u popisu literature. 


\subsubsection{Uokviravajuća integracija - pravo na stan i priuštivost stanovanja}

Uokviravajuća integracija uvjetno je rečeno „najslabiji“ (najneizravniji) mehanizam koji se odnosi na promjenu vjerovanja i očekivanja domaćih aktera, bez propisivanja institucionalnog modela ili promjene domaćeg institucionalnog konteksta strategijske interakcije. Kognitivna logika tog mehanizma podrazumijeva izvrtanje kauzalnog odnosa; vrijednosna promjena domaćih aktera utječe na njihove strategije i preferencije, što se u konačnici može odraziti i na domaću institucionalnu promjenu. Unatoč činjenici da bi se u određenom vidu moglo gledati na genezu policy okvira integriranog održivog urbanog razvoja kao na oblik uokviravajuće integracije, promocija prava na stan, priuštivog stanovanja te standardizacija kvalitete stanovanja u većoj mjeri korespondira kognitivno shvaćenom procesu „mekane“ europeizacije jer nije izravno podržan sredstvima iz fondova EU-a.

Pravo na stan podrazumijeva kognitivni utjecaj europeizacije, kojim se željelo poduprijeti konvergenciju civilizacijskih standarda europskih zemalja, u koje spada i pristojno stanovanje. Vrijednosno ishodište europske socijalne politike nakon Rimskog ugovora i osnivanja Europskog socijalnog fonda predstavlja Europska socijalna povelja (1961.) Vijeća Europe. Naknadna revidirana verzija usvojena je 1996. godine te sadrži proširen skup socijalnih prava. Tako se, primjerice, članak 31. (revidirane) Europske socijalne povelje tiče prava na stan, čime se stranke (države potpisnice) obvezuju da će (Vijeće Europe, 1997.:50): promicati ostvarenje zadovoljavajuće razine stanovanja, spriječiti ili smanjiti beskućništvo s ciljem njegove postupne eliminacije, učiniti troškove stanovanja prihvatljivim osobama koje ne raspolažu dostatnim sredstvima. Pet godina nakon objave revidirane Europske socijalne povelje Odbor za socijalnu koheziju Vijeća Europe usvaja dokument naziva Pristup socijalnim pravima u Europi (2002.), u kojem su problematizirani dosezi različitih europskih zemalja u području stanovanja (Vijeće Europe, 2003.): nepostojanje definicije minimalnih standarda stanovanja i definirane odgovornosti javne vlasti u tom području, kvalitativni (veličina, tip i udobnost) i kvantitativni (nedovoljna ponuda) manjak stanova te nedostatak političke volje za ublažavanjem posljedica privatizacije stanovanja, problem priuštivosti kao prepreka u ostvarivanju prava na stan kao socijalnog prava te nedostatak informacija o međunarodnim ugovorima i njihovu značenju za nacionalne stambene politike. Sankcije ${ }^{21}$ Vijeća Europe uslijed eventualnog odstupanja pojedine države (stranke) od promocije prava navedenih u Europskoj socijalnoj povelji simboličke su naravi, a ne materijalne. Implicitno se pretpostavljalo da će povećanje društvene transparentnosti uzrokovati povećani nadzor primjene Povelje zbog aktivnog sudjelovanja nevladinih organizacija, sindikata i drugih inicijativa, čime izvještavanje ili njegov manjak ne bi bio isključivo obaveza predstavnika vlasti.

21 Svojevrsnu iznimku predstavlja Europski sud za ljudska prava (ECHR), koji pruža pojedincima mogućnost žalbe, a naknadno i tužbe, na račun određene države u slučaju nemogućnosti ostvarenja ljudskih prava unutar te države. Beskućništvo, stambeno isključivanje i neadekvatno stanovanje mogu poslužiti kao instance nepoštivanja ljudskih prava. Članak 8. Europske konvencije za zaštitu ljudskih prava $i$ temeljnih sloboda tiče se univerzalnog prava na poštivanje privatnog i obiteljskog života, doma i dopisivanja. U određenim okolnostima dom se može protumačiti kao stan, pa su deložacije i neadekvatno stambeno zbrinjavanje bile osnove za tužbu protiv pojedinih država. 


\section{Stanovanje u doba krize}

Narativ o krizi u SAD-u i EU-u dobro je poznat i istražen podjednako iscrpno od autora lijeve i desne ideološke provenijencije. Ishodište se krize, prema današnjoj akademskoj ljevici, nalazi u dugoročnom problemu „prekršenog društvenog ugovora“ (Graeber, 2013.) u SAD-u s kraja 1970-ih, kada su postindustrijski porast nesigurnosti zaposlenja i opća stagnacija nadnica niže i srednje klase umjesto aktivnom socijalnom politikom ublaženi povećanim pristupom kreditiranju - posebice hipotekarnom - čime je otpočeo višedesetljetni uzlazni trend zaduživanja kućanstava (Blyth, 2013.; Hemerijck, 2013.; Streeck, 2014.). „Prekršenim društvenim ugovorom“ naziva se i povećanje nejednakosti, za koju Piketty (2014.:335-336) smatra da je jedan od temeljnih uzroka financijske krize jer je „zbog povećanja nejednakosti gotovo stagnirala kupovna moć niže i srednje klase u SAD-u, a to je moglo samo povećati trend sve većeg zaduživanja skromnih kućanstava, to više što su im banke i beskrupulozni financijski posrednici - željni dobrih prinosa od goleme financijske štednje koju su imućne kategorije građana ubacile u sustav - nudili kredite pod velikodušnim uvjetima“ (Piketty, 2014.:335-336). Slično intencionalističko objašnjenje logike u pozadini porasta zaduživanja kućanstava nudi i Varoufakis (2015.:117): „Uz stagnaciju plaća i upadljivo profiterstvo, marketinško isticanje novih modernih gadgeta kao uvjeta uspješnog života, banke su se domislile: zašto ne bi koristile sve veći priljev kapitala kojim su raspolagale (stranog kapitala, ali i onoga iz akumulacije domaćih profita) da kredite prošire na kućanstva iz srednje i radničke klase u obliku hipoteka i osobnih zajmova, te kreditnih kartica?"

Na desnici, Ferguson (2009.) smatra da postoje problemi s takvim narativom, poglavito u krivljenju dereguliranog financijskog sektora prije nego loše regulativne (antimonopolističke) politike. Ako je deregulirani financijski sektora kriv za financijsku krizu, onda je kriv i za dotadašnji gospodarski rast (usp. OECD, 2016.c). Sekuritizacija je smanjila cijenu zaduživanja, a milijuni pripadnika nižih slojeva (poglavito u Aziji) profitirali su od globalizacije financija i posljedičnog izlaska iz siromaštva. Također, čvrsta financijska regulacija nije spriječila kombinaciju dvoznamenkaste inflacije i recesije u SAD-u 1970-ih godina. Konačno, bankarski sektori kao što je njemački, kao simbol socijalno-tržišno usmjerenih gospodarstava Europe, trenutno imaju veće probleme od onog u SAD-u. Fukuyama (2014.:4) ipak nudi umjereniji odgovor rezimirajući da su uzročnici financijske krize podjednako javni (državne institucije) i privatni (investicijske banke) sektor u SAD-u, ali tvrdi da su „velike banke znale da će u konačnici biti spašene od države ukoliko upadnu u nevolju“.

Kriza u EU-u manifestirala se kroz tri sukcesivne, međusobno povezane krize: bankarsku krizu 2008. godine, ekonomsku recesiju 2009. te konačno fiskalnu krizu, koju se naziva i „suverenom dužničkom krizom“ (engl. sovereign debt crisis), kojom su u konačnici preko „periferijskih“ zemalja EU-a , primjerice Grčke, „zaražene” i najmoćnije europske države unutar eurozone zbog vezanosti uz jedinstvenu valutu (Hemerijck, 2013.:2). U trenutku koji Blyth (2013.) naziva „kejnezijanskim“ centralne su banke srezale kamatne stope gotovo do ništice, „ubrizgale“ milijarde eura u oslabljene bankarske sustave te kupovale državne obveznice najranjivijih gospodarstava (usp. Hemerijck, 2013.:7,341). Ubrzo je, 2009. godine, napuštena ideja dugoročnog 
intervencionizma kako bi se politikom štednje ${ }^{22}$ smanjilo javni dug (usp. OECD, 2016.a) koji je nastao kao posljedica spašavanja financijskog sektora.

Negativni utjecaj krize na EU vidljiv je u četirima područjima: (1) sektori, (2) izravna strana ulaganja (FDI), (3) siromaštvo, (4) javne financije (McCann, 2015.:10-13). Najbolji je primjer građevinski sektor, u kojem su na razini EU-a bruto dodana vrijednost i zaposlenje zabilježili pad od 3\% između 2007. i 2011. godine. U krizom najpogođenijim zemljama „kontrakcije“ su iznosile između 6\% i 20\%, s padom cijena imovine (stanovi, zemljišta i dr.) između 30\% i 50\%. Ostali pokazatelji bilježe porast siromaštva, pad izravnih stranih ulaganja, porast razina javnog duga u odnosu na BDP, ali i pad povjerenja u vlade gotovo svih država članica EU-a. ${ }^{23}$

Unatoč različitosti interpretacija uzroka financijske krize iz konzervativnog i progresivnog tabora, postoji konsenzus da je okidač bila subprime hipotekarna kriza, kasnije prisutna u različitim (ponajprije bankarskim) oblicima i u državama članicama EU-a. Temeljna proturječnost stambenih trendova u razvijenim državama članicama EU-a također je postala vidljivom. Negativna integracija podrazumijeva deregulirano, ali i globalizirano jedinstveno tržište EU-a, koje se prilagodilo trendu liberalizacije, pa su stambeni sustavi postali vrlo izloženi financijskim šokovima i krizama. Kombinacija trendova europeizacije i liberalizacije stambenih sustava sadrži razvojnu proturječnost iz razloga što ostvarenje ciljeva Kohezijske politike EU-a - koju se može interpretirati kao korektiv liberalizaciji stambenih sustava, ali i negativnoj integraciji - ovisi o sredstvima iz strukturnih (zajedničkih) fondova, a ona se prikupljaju iz proračuna država članica čiji su građani dominantno podnijeli teret krize zbog spašavanja institucija financijskog sektora. Države su članice zbog ugovornog poštivanja načela supsidijarnosti u stambenoj politici, politike štednje i uključenosti u jedinstveno tržište EU-a nastavile s fiskalnim mjerama koje podržavaju trend liberalizacije, čime dugoročno utječu na ponovno javljanje krize. Istodobno, koncept kohezivnog razvoja - u stanovanju operacionaliziran integriranim održivim urbanim razvojem - postaje problematičan kao takav jer podrazumijeva redistributivno24 korištenje sredstava iz razvojnih fondova EU-a, koja su posredno ograničena politikom štednje i ovise o profitabilnosti financijskih sektora država članica kao važnih nositelja ukupnog gospodarskog rasta.

22 Prema Blythu (2013.:2), „politika štednje oblik je dobrovoljne deflacije u kojoj se gospodarstvo prilagođava kroz smanjenje plaća, cijena, i javne potrošnje kako bi se obnovila konkurentnost, koja se (navodno) najbolje postiže rezanjem državnog proračuna, dugova i deficita“. 23

„Novi socijalni rizici“, kao što su deložacije, također se mogu smatrati pokazateljem krize. Vidi: Bonoli, 2005.

24 Prema reformiranoj kohezijskoj politici EU-a iz 2009. ona je oduvijek bila razvojna, a ne distributivna (McCann, 2015.:95). Takvo je objašnjenje dovedeno u pitanje kroz populističku kampanju zagovornika britanskog referenduma o izlasku iz EU-a (Brexit), u kojoj je upravo mnogo manji iznos sredstava povučen iz razvojnih fondova EU-a u odnosu na priložena bio jedan od temeljnih razloga zbog kojih bi Ujedinjeno Kraljevstvo trebalo napustiti EU. 
Proglašavanje prava na stan kao ljudskog prava koje se spominje u prikazanim dokumentima Vijeća Europe te pozivanje na implementaciju načela kao što su dekomodifikacija stanovanja, unaprjeđenje stanovanja marginalnih skupina i borba protiv špekulanata na stambenim tržištima zbog svojeg „mekanog“ utjecaja nisu mogli adekvatno ublažiti trend liberalizacije, iako su se dokumenti normativno protivni trendu usvajali tijekom njegovog najvećeg jačanja.

\section{Zaključak}

Na početku ovog rada željelo se ukazati na dominantne paradigme u području komparativnih stambenih studija. Divergentna paradigma uspjela je pomoću nekoliko teorija (strukture stambene opskrbe, stambenih statusa i stambene politike) dobro ocrtati statičnu sliku stambenih sustava grupiranih u klastere. Zatim su prikazani konvergentni, ali proturječni trendovi razvoja stanovanja u razvijenim državama EU-a te posljedice krize.

Može li se razriješiti ta proturječnost između trendova normativne standardizacije stambenih prava i kohezivnog razvoja financiranog iz strukturnih fondova EU-a, koji se naposljetku financiraju iz proračuna zemalja s visokim javnim dugom, s jedne strane, te trendovima komodifikacije i financijalizacije stanovanja (paradoksalno komplementarnim širenju jedinstvenog tržišta EU-a), koji naposljetku postaju uzročnici financijskih i stambenih kriza, s druge strane? Na temelju izloženih razmatranja ovdje se smatra da se ta proturječnost jedino može ublažiti, ali nikada u potpunosti razriješiti. Ključni akter ublažavanja svih kriza u prošlosti, ali i te proturječnosti fleksibilna je socijalna država sposobna za istovremenu regulaciju stambene financijalizacije, evolutivnu modernizaciju (europeizaciju) stambenog zbrinjavanja usvajanjem policy dosega stambenih prava i integriranog održivog urbanog razvoja te pridobivanje financijskih sredstava iz strukturnih razvojnih fondova EU-a.

Oslabljena tržišta, pad vrijednosti nekretnina i stambena kriza s predznakom nepriuštivosti stanovanja - za koju se uobičajeno smatra da nastupa kada dostigne iznos iznad 25\% raspoloživog dohotka kućanstva - najviše pogađaju društva u kojima ne postoji adekvatna zaštitna mreža uslijed velikog udjela privatnog vlasništva (usp. Kemeny, 1981., 1992.). Obuhvatnije socijalne države kao što su Švedska, Danska, Nizozemska, Austrija i Njemačka u ovoj su se krizi pokazale izdržljivijima pri smanjenju utjecaja opadanja agregatne potražnje i ublažavanju socijalnih nedaća (Hemerijck, 2013.:5). Također, na negativne utjecaje trendova liberalizacije i njihovu kulminaciju u krizi najotpornijima su se pokazale države čiji su stambeni sustavi korporativistički i državno-razvojni zbog veće mješovitosti stambenih statusa, zakonskog ograničenja ili zabrane sekuritizacije stanovanja te raznovrsnosti aktera stambene opskrbe osim tržišnih i državnih, gdje se ističu neprofitne i mješovite organizacije (kooperative, zadruge, stambene korporacije). Socijalne inovacije u području stanovanja (Czischke, 2013.) kao odgovor na posljedice krize (deložacije, zaduživanje, stambeno siromaštvo starijih i dr.) upravo nastaju kao plod dobre vladavine, odnosno ravnopravne suradnje svih dionika u stambenom zbrinjavanju. Dobre prakse navedenih država s razvijenim stambenim sustavima dominantno se vezuju uz koheziju, integrirani održivi urbani 
razvoj i adekvatne regulacijske mehanizme u slučaju pojave rizika i/ili negativnih posljedica konvergentnih trendova komodifikacije i financijalizacije stanovanja te krize. Iako je rasprostranjen mehanizam vezivanja gradova i neprofitnog sektora uz razvojne fondove EU-a, nacionalne (državne) stambene strategije i institucije još su uvijek neizostavni akteri stambenog zbrinjavanja stanovništva, a stambeni sustavi spomenutih država članica EU-a pokazali su se kao pozitivni primjeri odolijevanja izazovima suvremenog stambenog razvoja, te se mogu smatrati svojevrsnim putokazima za reformu stambene politike u smjeru sigurnijeg i kvalitetnijeg stanovanja.

\section{Literatura}

1. Aalbers, M. B. (2009). The Globalization and Europeanization of Mortgage Markets. International Journal of Urban and Regional Research, 33 (2): 389-410.

2. Aalbers, M. B. (2016). The Financialization of Housing: A Political Economy Approach. London and New York: Routledge.

3. Allen, J.; Barlow, J.; Leal, J.; Maloutas, T.; Padovani, L. (2004). Housing and Welfare in Southern Europe. Oxford: Blackwell Publishing.

4. Arbaci, S. (2007). Ethnic Segregation, Housing Systems and Welfare Regimes in Europe. European Journal of Housing Policy, 7 (4): 401-433.

5. Atterhog, M. (2006). The Effects of Government Policies on home ownership rates. An international survey and analysis, in: Doling, J. and Elsinga, M. (Eds.). Homeownership: getting in, getting from, getting out. Part II. Amsterdam: IOS Press.

6. Ball, M. (1983). Housing Policy and Economic Power. The Political Economy of Owner Ocupation. London and New York: Methuen.

7. Barlow, J. and Duncan, S. (1994) Success and failure in housing provision. European systems compared. Oxford: Pergamon Press.

8. Barr, N. (2012). Economics of the Welfare State. Oxford: Oxford University Press.

9. Bežovan, G.; Matković, T.; Puljiz, V.; Šućur, Z.; Zrinščak, S. (2005). Pojmovnik socijalne politike, U: Puljiz, V.; Bežovan, G.; Šućur, Z.; Zrinščak, S. (Ur.). Socijalna politika. Povijest. Sustavi. Pojmovnik. Zagreb: Pravni fakultet Sveučilišta u Zagrebu.

10. Blyth, M. (2013). Austerity. The History of a Dangerous Idea. Oxford: Oxford University Press.

11. Bonoli, G. (2005). The politics of the new social policies: providing coverage against new social risks in mature welfare states. Policy \& Politics, 33 (3): 431-49.

12. Briscoe, S. and Fuller, J. (2007). Financial Dictionary. Over 2,600 essential financial terms. Petersfield, Hampshire: Harriman House LTD.

13. Carpenter, J. (2013). Sustainable urban regeneration within the European Union: a case of Europeanization, in: Leary, M. E. and McCarhty, J. (Eds.). The Routledge Companion to Urban Regeneration. London i New York: Routledge.

14. Castells, M. (1977). The Urban Question. London: Edward Arnold.

15. Castells, M. (1980). Grad, klasa i moć. Revija za sociologiju, 10 (1-2): 47-52.

16. Czischke, D. (2013). Social Innovation in Housing: Learning from practice across Europe. Discussion paper commissioned by the Chartered Institute of Housing on behalf of the Butler Bursary. 
17. Dewilde, C. (2016). The Financialization of Housing and Affordability in the Private Rental Sector. HOWCOME Working Paper Series, No. 15. Tilburg: Tilburg University.

18. Donnison, D. V. (1967). The Government of Housing. Harmondsworth: Penguin.

19. Epstein, G. A. (2005). Introduction: Financialization and the World Economy, in: Epstein, G. A. (Ed.). Financialization and the World Economy (p. 3-17). Cheltenham i Northampton: Edward Elgar Publishing.

20. Esping-Andersen, G. (1990). The Three Worlds of Welfare Capitalism. Princeton: Princeton University Press.

21. Esping-Andersen, G. (1999). Social Foundations Of Postindustrial Economies. Oxford: Oxford University Press.

22. European Commission (2010). Europe 2020: A strategy for smart, sustainable and inclusive growth. Pregledano 29. lipnja 2016. (http://ec.europa.eu/eu2020/ pdf/COMPLET\%20EN\%20BARROSO \%20\%20\%20007\%20-\%20Europe $\% 20$ 2020\%20-\%20EN\%20version.pdf).

23. European Commission (2016). Financial execution by period, fund, country. Pregledano 4. listopada 2016. (http://ec.europa.eu/regional_policy/sources/ docgener/evaluation/data/financial execution by period fund country.xls).

24. Europski parlament (2007). Europska stambena povelja. Revija za socijalnu politiku, 14 (3-4): 391-399.

25. Eurostat (2016). Podjela stanovnika prema statusu stanovanja, 2014. Pregledano 21. srpnja 2016. (http://ec.europa.eu/eurostat/statistics-explained/index. php/File:Distribution of population by tenure status, 2014 ( $\% 25$ of population) YB16.png).

26. Ferrera, M. (1996). The 'Southern Model' of Welfare in Social Europe. Journal of European Social Policy, 6 (1): 17-37.

27. Ferguson, N. (2009). Diminished Returns. New York Times (15. svibnja). Pregledano: 9. srpnja 2016. (http://www.nytimes.com/2009/05/17/magazine/17wwlnlede-t.html? r=0).

28. Ferguson, N. (2014). Uspon novca. Financijska povijest svijeta. Drugo izdanje. Zagreb: Profil.

29. Fukuyama, F. (2014). Political Order and Political Decay. From the Industrial Revolution to the Globalization of Democracy. New York: Farrar, Straus and Giroux.

30. Graeber, D. (2014). Dug. Prvih 5000 godina. Zagreb: Faktura. 
37. Informal Council of Ministers responsible for Urban Affairs (2000). Lille Action Programme. Pregledano 3. kolovoza 2016. (http://www.eukn.eu/e-library/project/bericht/eventDetail/lille-action-programme/).

38. Informal Ministerial Meeting on Sustainable Communities (2005). Bristol Accord. Pregledano 4. kolovoza 2016. (http://www.eib.org/attachments/jessica_bristol_ accord sustainable communities.pdf).

39. Informal Ministerial Meeting on Urban Development (2007). Leipzig Charter on Sustainable European Cities. Pregledano 23. srpnja 2016. (http://ec.europa.eu/ regional policy/archive/themes/urban/leipzig charter.pdf).

40. Informal Ministerial Meeting on Urban Development and Territorial Cohesion (2007). Territorial Agenda of the European Union. Towards a More Competitive and Sustainable Europe of Diverse Regions. Pregledano 20. srpnja 2016. (http:// ec.europa.eu/regional_policy/sources/policy/what/territorial-cohesion/territorial agenda leipzig2007.pdf).

41. Informal Ministerial Meeting on Urban Development (2008). Marseille Declaration. Pregledano 24. srpnja 2016. (http://www.eib.org/attachments/jessica marseille statement en.pdf).

42. Informal Ministerial Meeting on Urban Development (2010). Toledo Declaration. Pregledano 29. srpnja 2016. (http://ec.europa.eu/regional_policy/archive/ newsroom/pdf/201006 toledo_declaration_en.pdf).

43. Informal Ministerial Meeting of Ministers responsible for Spatial Planning and Territorial Developmenton (2011). Territorial Agenda of the European Union 2020. Towards an Inclusive, Smart and Sustainable Europe of Diverse Regions. Pregledano 2. kolovoza 2016. (http://www.nweurope.eu/media/1216/territorial agenda 2020.pdf).

44. Informal Meeting of EU Ministers Responsible for Urban Matters (2016). Urban Agenda for the EU. Pact of Amsterdam. Pregledano 20. srpnja 2016. (http:// ec.europa.eu/regional_policy/sources/policy/themes/urban-development/ agenda/pact-of-amsterdam.pdf).

45. Kemeny, J. (1981). The Myth of Homeownership. Public versus Private Choices in Housing Tenure. London: Routledge and Kegan Paul.

46. Kemeny, J. (1992). Housing and Social Theory. London: Routledge.

47. Kemeny, J. (1995). From Public Housing to the Social Market: Rental Policy Strategies in Comparative Perspective. London: Routledge.

48. Kemeny, J. (2001). Comparative housing and welfare: Theorising the relationship. Journal of Housing and the Built Environment, 16 (1): 53-70.

49. Kemeny, J. (2004). Home ownership against the welfare state: the thesis and the evidence. ENHR konferencija, Cambridge University: 2.-6. July 2004.

50. Kemeny, J. and Lowe, S. (1998). Schools of Comparative Housing Researach: From Convergence to Divergence. Housing Studies, 13 (2): 161-176.

51. King, P. (2016). The Principles of Housing. New York and London: Routledge.

52. Knill, C. and Lehmkuhl, D. (1999). How Europe Matters. Different Mechanisms of Europeanization. European Integration online Papers (EIoP), 3 (7).

53. Kraemer-Eis, H.; Passaris, G.; Tappi, A.; Inglisa, G. (2015). SME Securitisation at a crossroads? Working Paper 2015/31. Pregledano 4. listopada 2016. (http:// www.eif.org/news centre/publications/eif wp 31.pdf).

54. MacPherson, C. D. (1981). Politička teorija posesiunog individualizma. Zagreb: Centar za društvene djelatnosti SSOH. 
55. McCann, P. (2015). The Regional and Urban Policy of the European Union. Cobesion, Results-Orientation and Smart Specialisation. Cheltenham and Northampton: Edward Elgar Publishing.

56. McCormick, J. (2010). Razumjeti Europsku uniju. Zagreb: MATE.

57. Matznetter, W. (2006). Quo vadis, comparative housing research? Rad predstavljen na ENHR konferencija, Ljubljana, Slovenija: 2.-5. July 2006.

58. Merton, R. K. (1979). O teorijskoj sociologiji. Zagreb: Centar za društvene djelatnosti SSOH.

59. Mullins, D. Murie, A. (2006). Housing Policy in the UK. New York: Palgrave Macmillan.

60. OECD (2016.a). General government debt (indicator). Pregledano 19. srpnja 2016. (https://data.oecd.org/gga/general-government-debt.htm).

61. OECD (2016.b). Analytical House Price Indicators. Pregledano 1. kolovoza 2016. (https://stats.oecd.org/Index.aspx?DataSetCode=HOUSE PRICES).

62. OECD (2016.c). Level of GDP per capita and productivity. Pregledano 3. kolovoza 2016. (https://stats.oecd.org/Index.aspx?DataSetCode=PDB LV).

63. Pandžić, J. (2017). Modernizacija stambene politike u postsocijalističkim državama članicama EU (radni naslov). U pripremi.

64. Piketty, T. (2014). Kapital u dvadeset proom stoljeću. Zagreb: Profil.

65. Przeworski, A. (1986). Capitalism and Social Democracy. Cambridge: Cambridge University Press.

66. Raedelli, C. M. (2004). Europeanisation: Solution or problem? European Integration online Papers (EIOP), 8 (16).

67. Reinhart, C. M. and Roggof, K. S. (2011). This Time is Different. Eight Centuries of Financial Folly. Princeton and Oxford: Princeton University Press.

68. Ronald, R. (2008). The Ideology of Homeownership. London i New York: Routledge.

69. Schwartz, H. and Seabrooke, L. (2009) Varieties of Residential Capitalism in the International Political Economy: Old Welfare States and the New Politics of Housing, in: Schwartz, H. and Seabrooke, L. (Eds.). The Politics of Housing Booms and Busts. New York: Palgrave Macmillan.

70. SIFMA (2016). Europe Securitization Issuance. Pregledano 30. srpnja 2016. (https: $/ /$ www.google.hr/url?sa $=t \& r c t=j \& q=\&$ esrc $=s \&$ source $=$ web\&cd $=1 \& v e d=0 a h U$ KEwipkY34prfOAhXD2hoKHezZAIMQFggfMAA\&url=https\%3A\%2F\%2Fwww. sifma.org $\% 2$ Fuploadedfiles $\% 2$ Fresearch $\% 2$ Fstatistics $\% 2$ Fstatisticsfiles $\% 2$ Fsf-eur ope-securitisation-afme-sifma.xls\&usg=AFQjCNFPzdycLhbzZuabZcjnm8Fhe9CL $\underline{\mathrm{hA}}$.

71. Soto, P. (2013). Cities of Tomorrow-Action Today. Urbact II Capitalisation. Key Messages. Saint-Denis: URBACT.

72. Stephens, M.; Lux, M. and Sunega, P. (2015). Post-socialist housing systems in Europe: Housing welfare regimes by default? Housing Studies, 30 (8): 1210-1234.

73. Streeck, W. (2014). How Will Capitalism End? New Left Review, 87: 35-64.

74. Torgersen, U. (1987). Housing: the Wobbly Pillar under the welfare state, in: Turner, B.; Kemeny, J. and Lundqvist, L. (Eds.). Between State and Market: Housing in the Post-Industrial Era. Stockholm: Almqvist and Wiksell.

75. URBAN cities and players (2005). The ,Acquis URBAN'. Using Cities'Best Practises for European Cohesion Policy. Pregledano 25. srpnja 2016. (http://ec.europa.eu/ regional_policy/archive/newsroom/document/pdf/saarbrucken_urban_en.pdf). 
76. Varoufakis, Y. (2015). Globalni minotaur. Zagreb: Profil.

77. Vijeće Europe (1997). Europska socijalna povelja (revidirana). Revija za socijalnu politiku, 4 (1): 41-53.

78. Vijeće Europe (2003). Pristup socijalnim pravima u Europi: stvarno stanje. Revija za socijalnu politiku, 10 (2): 199-215. 
Pregledni rad

Josip Pandžić

University of Zagreb, Faculty of Law, Social Work Study Centre, Croatia

e-mail:jpandzic@pravo.hr

\title{
Contradictions of Housing Policies in Developed EU States
}

\begin{abstract}
In the last half century of comparative research, the development of housing has manifested itself as an ambivalent and empirically hard-to-measure object of study. In time, researchers' labour resulted in a threefold division between juxtapositional, convergence and divergence paradigms. The divergence paradigm in which various "middle range theories" are included is the most developed paradigm in comparative housing studies at the moment and it will be used for a preliminary description of differences and similarities among European countries with regards to housing. Despite the housing convergence paradigm's marginalised research status, the goal of this paper is its revitalisation in housing studies by way of conducting a comparative analysis of contradictions of convergence trends of housing policy liberalization and europeanization which directly or indirectly relate to housing changes in developed member states of the EU. The contradictions of convergence housing policies' trends have been problematized separately using the example of the 2008 global financial crisis, the consequential crisis in the EU and their impact on housing.
\end{abstract}

Key words: housing, development, divergence, convergence, contradiction, liberalization, europeanization, crisis. 